\title{
Regional brain extracellular markers of cerebral ischaemia after aneurysmal subarachnoid haemorrhage: a combined cerebral microdialysis and perfusion CT study
}

\author{
C Patet $^{1 *}$, T Suys $^{1}, \mathrm{H}$ Quintard ${ }^{2}$, J-B Zerlauth ${ }^{3}$, M Oddo $^{1}$
}

From ESICM LIVES 2015

Berlin, Germany. 3-7 October 2015

\section{Introduction and Objectives}

Detection of cerebral ischemia after aneurysmal subarachnoid hemorrhage (SAH) remains challenging, particularly in comatose patients. The aim of this study was to examine the value of cerebral microdialysis (CMD) to predict cerebral ischemia, diagnosed by perfusion CT (PCT) imaging.

\section{Methods}

We analyzed 48 PCT from 20 SAH patients (age $59 \pm 8$ years, median WFNS 4 [interquartile range 3-5]) monitored with CMD (in apparently normal brain) as part of standard care. PCT was categorized as ischemic (cerebral blood flow $[\mathrm{CBF}]<32.5 \mathrm{~mL} / 100 \mathrm{~g} / \mathrm{min}$ with a mean transit time $>5.7 \mathrm{sec}$ ) vs. non-ischemic. Cerebral extracellular levels of lactate/pyruvate ratio (LPR) $>40$ with glucose $<$ $1.0 \mathrm{mmol} / \mathrm{L}$ were used as thresholds for brain tissue ischemia (BTI).

\section{Results}

Regional CBF (around the CMD probe) correlated significantly with global CBF (averaged from bilateral anterior and middle cerebral arteries; Pearson's $r=0.70$, $p<0.0001$; Figure 1).

Ischemic PCT ( $\mathrm{n}=13 ; 10$ patients) showed higher CMD LPR $(48 \pm 37$ vs. $30 \pm 10$ in non-ischemic PCT) and lower CMD glucose $(0.9 \pm 0.8$ vs. $1.4 \pm 0.8 \mathrm{mmol} / \mathrm{L}$; both $p<0.001)$. BTI was more frequent in ischemic PCT (32\% vs. $4 \%, p<0.0001$; Figure 2 ) and correlated significantly with cerebral ischemia on PCT (correlation

${ }^{1}$ CHUV - Lausanne University Hospital, Neuroscience Critical Care Research

Group - Intensive Care Medicine, Lausanne, Switzerland

Full list of author information is available at the end of the article

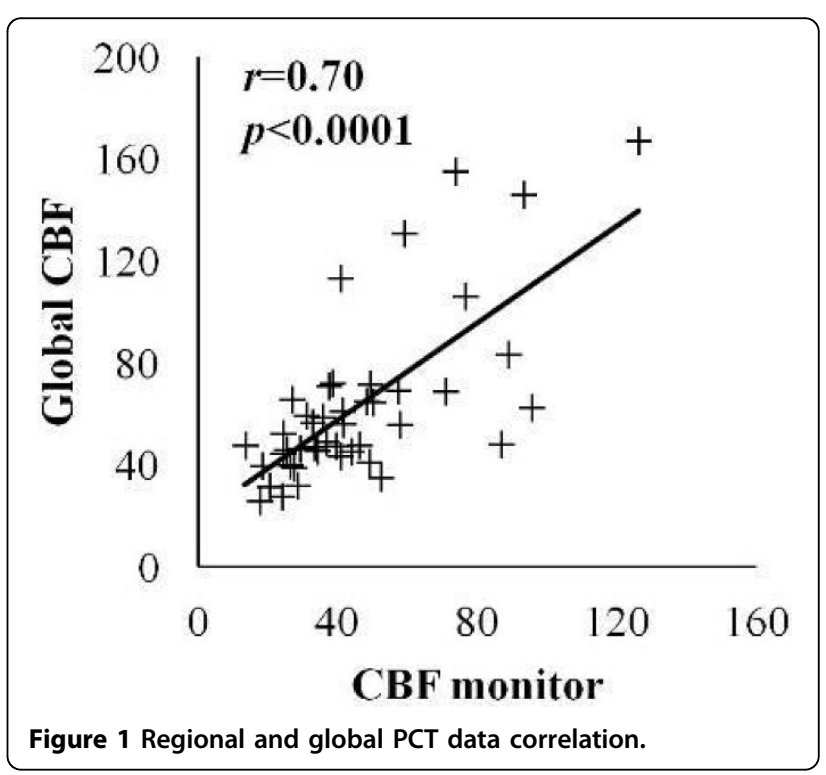

coefficient 2.72 [95\% confidence interval 1.11-6.63], $p=$ 0.028; generalized estimated equations analysis). A CMD pattern of BTI had a $72 \%$ positive predicted value and an $81 \%$ negative predictive value for detecting cerebral ischemia on PCT.

\section{Conclusions}

Cerebral microdialysis appears accurate to detect cerebral ischemia at the bedside in comatose SAH patients and may be a valid complementary neuromonitoring tool in this setting. 

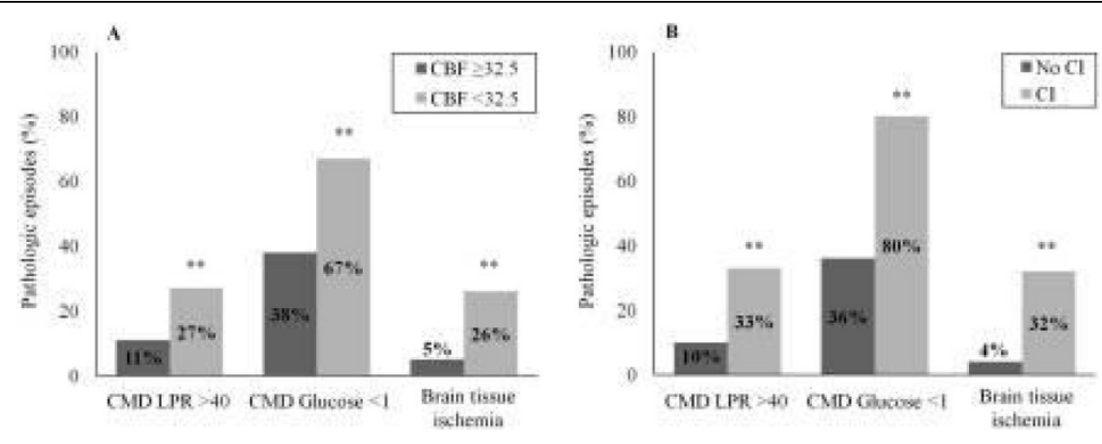

Figure 2 CMD pathologic samples according to PCT.

\section{Grant acknowledgment}

Supported by Grants from the Swiss National Science Foundation and The Novartis Foundation for Biomedical Research.

\section{Authors' details}

'CHUV - Lausanne University Hospital, Neuroscience Critical Care Research Group - Intensive Care Medicine, Lausanne, Switzerland. ${ }^{2}$ Nice University Hospital, Anesthesia and Critical Care, Nice, France. ${ }^{3} \mathrm{CHUV}$ - Lausanne University Hospital, Radiology, Lausanne, Switzerland.

Published: 1 October 2015

doi:10.1186/2197-425X-3-S1-A814

Cite this article as: Patet et al:: Regional brain extracellular markers of cerebral ischaemia after aneurysmal subarachnoid haemorrhage: a combined cerebral microdialysis and perfusion CT study. Intensive Care Medicine Experimental 2015 3(Suppl 1):A814.

\section{Submit your manuscript to a SpringerOpen ${ }^{\mathcal{O}}$} journal and benefit from:

- Convenient online submission

- Rigorous peer review

- Immediate publication on acceptance

- Open access: articles freely available online

- High visibility within the field

- Retaining the copyright to your article 